\title{
Mendialogkan Kehidupan Keagamaan
}

\author{
Mudjahirin Thohir \\ Prodi Sastra Indonesia, Fakultas Ilmu Budaya, Universitas Diponegoro \\ mudjahirinthohir@ymail.com
}

\begin{abstract}
In the social life, the religion have two faces: conflict and peace. Conflict arises in many reasons, one of them is ethnocentric views. Peace condition comes because all of religion advocates to living in harmony. The two phenomena were studied in the discussion of the religious leaders in the Organization of the Religious Harmony Forum (FKUB) Central Java. Result of the workshop are: (1) to avoid conflict, do not take ethnocentric views; (2). The truth of religion is absolute in relative term; (3) the religious community must have a principle that the different is beautiful; (4) the last but not lease, needed to form interfaith community in some areas with different religions.
\end{abstract}

Key words: religion, conflict, harmony, ethnocentrict, absolute in relative term, beautiful, and interfaith community.

\section{INTISARI}

Dalam kehidupan sosial, agama menghadirkan dua kemungkinan: konflik atau damai. Konflik timbul salah satu alasannya karena pandangan etnosentrik, sementara damai hadir karena agama mengajarkan untuk hidup rukun. Dua fenomena tersebut dikaji dalam sarasehan Forum Kerukunan Umat Beragama (FKUB) Jawa Tengah. Hasil sarasehan tersebut ialah: (1) Untuk mencegah konflik, jangan berpandangan etnosentris; (2) memandang kebenaran agama adalah absolut secara relatif; (3) perlu berpinsip bahwa perbedaaan adalah keindahan; dan (4) perlunya dibentuk paguyuban lintas agama dalam masyarakat yang beragam keagamaan.

Kata-kata kunci: agama, konflik, kerukunan, etnosentrik, absolut secara relatif, keindahan perbedaan, dan paguyuban.

\section{PENDAHULUAN}

Indonesia merdeka berkat perjuangan warga bangsa yang di samping berbeda-beda suku, agama, ras, dan antargolongan, juga mereka tinggal di dalam kawasan yang berbeda-beda pula. Mereka kemudian disatukan dalam geopolitik Indonesia. Ini berarti bahwa sebelum Indonesia itu menjadi negara merdeka, mereka dengan kebudayaan dan agama yang dianutnya itu telah ada, dan keberadaan mereka yang berbeda-beda suku, agama, ras dan antergolongan tadi, bukanlah sebagai penghambat untuk mewujudkan 
dan terwujudkan suatu negara merdeka bernama Negara Kesatuan Republik Indonesia (NKRI) (Abegebriel, 2014; Thohir, 2013)

Dalam perjalanannya kemudian, bangsa ini mengalami pasangsurut, bahkan konstelasi dan ketegangan yang dipicu oleh berbagai kepentingan luar maupun dalam negeri sendiri. Di antara konstelasi dan ketegangan di dalam negeri ialah adanya sejumlah pihak atau kelompok dari suatu paham politik keagamaan yang berusaha memperebutkan dasar pijakan negara agama dalam satu segi, dan adanya respons negatif dari kelompok keagamaan yang lain yang tetap ingin menjaga kesatuan bangsa ini dengan dasar Pancasila.

Akibat dari kecenderungan yang berbeda yang dibungkus dengan politik keagamaan demikian inilah, pilihan agama sepertinya memicu dan memacu konflik sosial. Untuk itu, perlu mendialaogkan mengenai akar dari terjadinya "titik tengkar keagamaan dalam satu sisi, dan kemudian bagaimana mengelola pertengkaran itu menjadi titik temu keagamaan untuk kesatuan dan penyatuan bangsa ini ke depan". Tulisan ini akan mengkaji hal tersebut dilihat dari perspektif antropologis, yakni bagaimana para elit keagamaan melihat realitas warga bangsa yang plural ini. Pertanyaan penting yang perlu diajukan ialah, bagaimana konflik antarumat beragama itu muncul dan dimunculkan? Apa sesungguhnya akar di balik konflik tersebut kalau dlihat dari perspektif antroposentrik?

\section{METODE PENELITIAN}

Untuk mengkaji dua persoalan di atas, dilakukan dua bentuk kegiatan guna didapatkan data yang memiliki relevansi dan keakuratan. Pertama dengan cara sarasehan kepada sejumlah pelaku yang terwakili oleh mereka yang tergabung dalam kepengurusan Forum Kerukunan Umat Beragama (FKUB). ${ }^{1}$ Sarasehan dimaksud berfokus pada mendialogkan masalah sebagaimana fokus kajian, lalu yang kedua, melakukan analisis atas pandangan-pandangan partisipan sarasehan. Berbagai pandangan partisipan tersebut kemudian dikategorisasikan dan dilihat dari perspektif antroposentrik.

1 Sarasehan dilakukan di Pekalongan pada tanggal $30-31$ Agustus 2018, di Pekalongan. Sarasehan ini diinisiasi oleh kantor Kesbangpol Jawatengah, sebagai penyandang dana. Sedang partisipan sarasehan adalah utusan pengurus Forum Kerukunan Umat Beragama (FKUB) se Jawa Tengah. 
Perspektif antroposentrik ialah perspektif menurut kacamata partisipan sarasehan, pemeluk agama terkait bagaimana mereka memandang ajaran agamanya sendiri dan memandang agama di luarnya (Thohir, 2013: 15).

Atas dasar perspektif ini kemudian persoalan konflik dan kerukunan umat beragama dilihat berdasarkan tiga variabel, yaitu (1) pengetahuan keagamaan, (2) interaksi antarumat yang berbeda agama; dan (3) adanya kompetisi baik yang terkait dengan masalah sosiologis maupun teologis. Berdasarkan pada tiga variabel ini berarti bicara soal kerukunan dan toleransi umat lintas agama hanya relevan ketika di dalam masyarakat tersebut, memang masing-masing memiliki pengetahuan dasar atas agama yang dipeluk, berinteraksi secara terus menerus, dan berkompetisi baik untuk kepentingan pengembangan agamanya maupun kepentingan di luar persoalan agama seperti kompetisi memperebutkan peluang-peluang terbatas.

\section{HASIL PENELITIAN}

\section{a. Akar Konflik antarumat Beragama}

Jika terkadang bahkan sering terjadi benturan antarumat beragama, apakah benturan seperti itu karena perintah ajaran agama yang kita peluk atau karena umat itu sendiri yang belum bisa melihat berbedaan sebagai rahmat melainkan lebih melihatnya sebagai ancaman? Atau benturan itu sendiri terjadi sesungguhnya berada di luar persoalan ataupun kepentingan agama hanya saja diseret-seret ke alasan karena perbedaan agama? Di sinilah titik tolak dari cara memahami ajaran dari agama yang dianut dengan ajaran agama di luarnya. Di antara kedua titik tolak cara pandang demikian, memungkinkan umat bisa hidup dalam situasi yang mendamaikan atau meresahkan. 


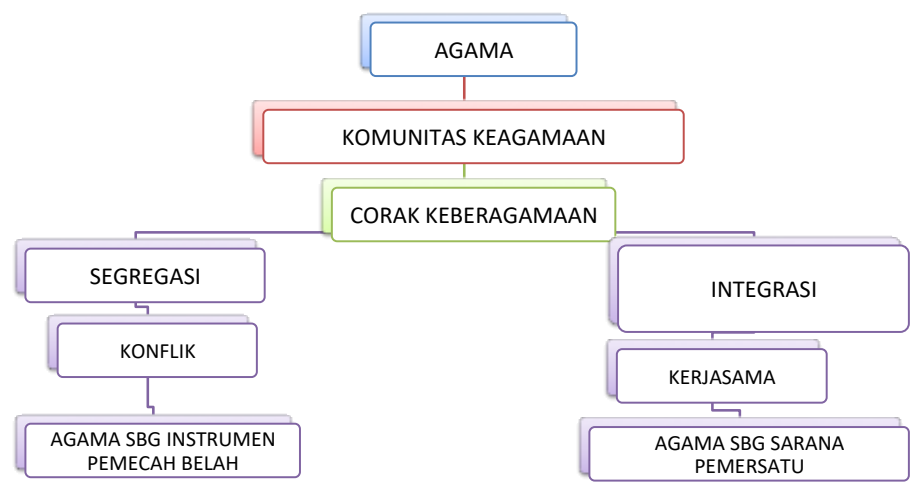

Pertanyaan kepada partisipan sarasehan, "mengapa terjadi ketegangan bahkan konflik antarumat beragama?". Secara umum melihat bahwa persoalan pertamanya adalah pada cara bagaimana umat itu memandang ajaran agama lain, yaitu dengan cara pandang etic (etic perspective) atau etnosentris (Thohir, 2013) yaitu mengukur ajaran pihak lain dengan kacamata ajaran agamanya sendiri. Pada saat yang sama, memperlakukan ajaran diri bersifat mutlak (absolut) yakni berlaku umum bagi umat manusia, tidak dibatasi kepada umat dari penganut agama itu sendiri. Dengan kata lain, orang yang mengakui sebagai umat beragama tetapi dalam dirinya ada perasaan untuk menghakimi ajaran agama lain lewat pemahaman dari sudut ajaran agama yang dipeluknya". Efek yang timbul dari cara pandang demikian ialah akan mudah menjadikan agama sebagai pemilah antarumat itu sendiri, kendati mereka sudah hidup bersama dalam lingkungan sosialnya.

Jika yang terjadi memang demikian, maka agama mengkonstruksi dan dikonstruksi oleh umat sebagai instrument pemilahan sosial. 


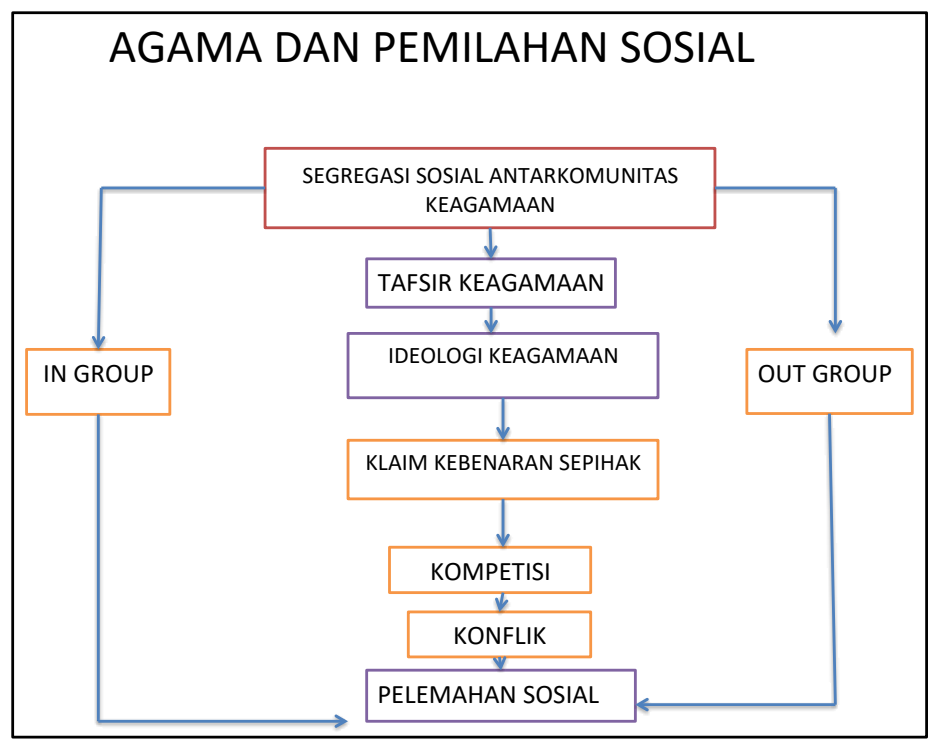

Kalau terkonstruksi seperti ini, maka pada gilirannya persaingan dalam berbagai ranah kehidupan seperti ekonomi, politik, budaya dan lain sebagainya - akan dengan mudah memanfaatkan sentimen-sentimen sosial keagamaan untuk memperebutkan kemenangan. Dari semangat semacam inilah yang sering menjadi pemicu konflik (lihat pada Nugroho, 2016; Waskitoadi, 2017).

Kalau gejala atau bahkan faktanya yang ditemukan dalam kehidupan riil di lapangan ialah sudah menunjukkan hal demikian, berarti identitas keagamaan itu menjadi momok yang harus diwaspadai bagi umat yang berbeda agama. Benarkah para penganut masing-masing agama itu menginginkan kondisi seperti ini?

Jika tidak menginginkan "kegaduhan" yang alat picunya agama (yang berbeda) yang dipeluk oleh warga bangsa kita, dan sebaliknya, kita menginginkan keharmonisan hidup di antara para pemeluk agama dan aliran keagamaan yang berbeda-beda dalam masyarakat plural seperti masyarakat Indonesia, dari mana harus dimulai dan dengan cara bagaimana memulainya?

Menurut kesepahaman partisipan sarasehan, persoalan di atas harus dicarikan jalan keluarnya. Menurut mereka, perlu memahami alasan di balik adanya perbedaan secara positif ialah sifat ajaran agama yaitu ekslusif dan inklusif sekaligus. Sifat eksklusif agama adalah benar untuk umatnya, dan tidak untuk agama di luarnya". Sebagai ilustrasi dari sifat eklusifitas agama itu ialah, ungkapan dalam paham umat 
Islam, "bahwa sesungguhnya hanya Islamlah agama yang diridhoi Allah", atau paham umat Kristiani bahwa "tidak ada kebenaran di luar gereja".

Menurut partisipan sarasehan, paham itu harus dikembalikan untuk kepentingan meneguhkan iman pemeluknya, dan tidak untuk diperlakukan kepada mereka yang berada di luarnya. Jadi dogma itu harus diposisikan sebagai "relatively absolute", absolut yang relatif. Inilah paham inklusif keagamaan yang perlu hadir dalam masyarakat plural.

Konsep "relatively absolute" (Thohir, 2018) itu jika diterjemahkan dalam konstruksi sosiologis menjadi "kebenaran itu bukan tidak terbatas, tetapi berbatas". Pesan yang ingin disampaikan dalam konstruksi kehidupan masyarakat plural menuju kepada kedewasaan beragama ialah "kebenaran agama itu pasti benar bagi umatnya dan tidak ditujukan kepada umat di luarnya, sebab masing-masing umat memiliki keyakinan yang sama atas ajaran agama yang dipeluknya".

Menurut partisipan sarasehan, kesepakatan atas paham itu merupakan modal sosial keagamaan untuk bisa hidup dalam kerukunan. Jika satu dalam ke-ummat-an merupakan kerahmatan. Sedang jika berbeda dalam pilihan keagamaan itulah sunnatullah alias kehendak Pencipta Perbedaan. Lewat paham ini, sama atau berbeda, tidak akan menghalangi untuk menghormati, menerima kehadiran orang yang berbeda agama, dan memungkinkan untuk bekerja sama.

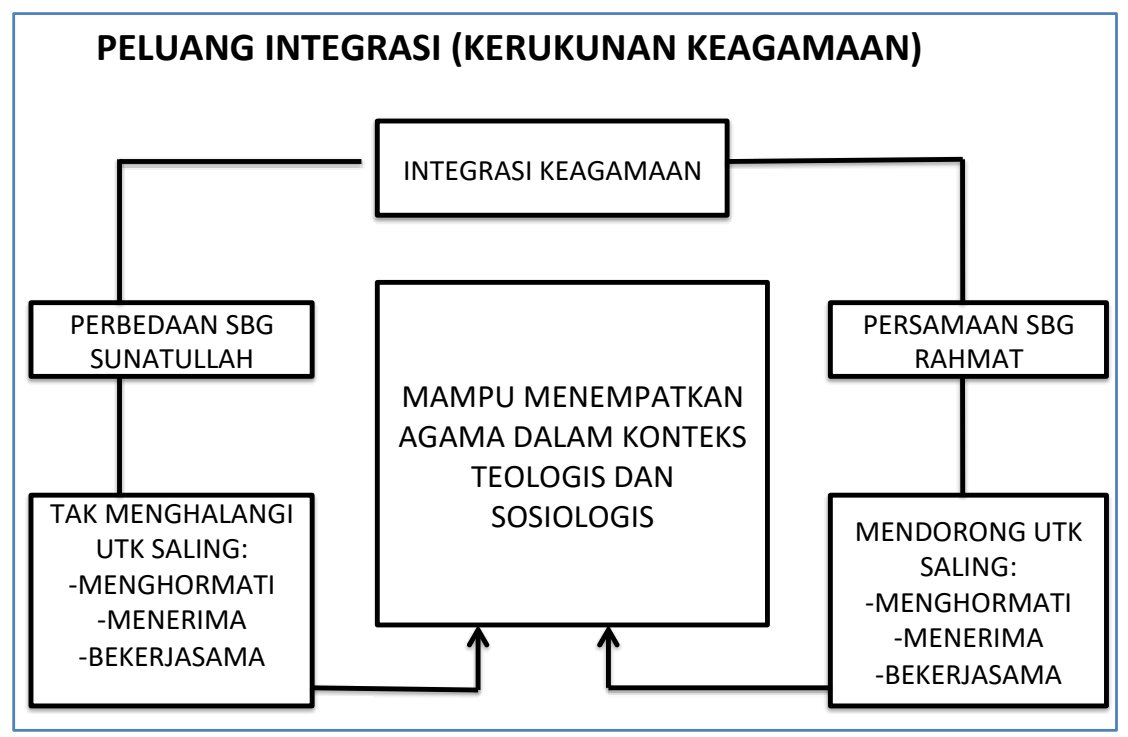




\section{b. Mengelola Kehidupan Keagamaan}

Bagaimana mendudukkan ajaran agama yang dipeluk tanpa mengurangi ke-iman-an diri dalam satu sisi, dan memperlakukan secara terhormat kepada sesama umat yang berbeda pilihan agamanya?

Menurut partisipan, membicara soal kerukunan dan toleransi keagamaan perlu didasarkan pada ajaran agama itu sendiri. Untuk itu, kita perlu membongkar tafsir-tafsir keagamaan yang tidak tepat seperti pemutlakan diri dan penghakiman negatif kepada kelompok di luarnya. Kita bisa memulai misalnya dari pemahaman dimensional keagamaan baru kemudian dilanjutkan dalam praktik kehidupan keseharian.

Dari dimensi keagamaan itu sendiri, terdapat dua dimensi yang perlu berjalan secara seimbang dan bertautan yaitu dimensi teologis (ke-Ilaahi-an) dan dimensi sosiologis (kemanusiaan). Pada dimensi teologis, setiap agama diberi ruang yang sah untuk mendifinisikan kebenaran mutlak atas agama yang dipeluk oleh umatnya sehingga umat tidak ragu-ragu atas pilihannya itu.

Kebenaran mutlak dalam dimensi teologis menjelaskan bahwa agama bercorak sakral (lihat Effendi, 1997; Mas'udi, 2009). Jika tidak bercorak sakral maka nasib agama akan sama dengan partai politik, di mana masing-masing anggotanya bermain "kutu-loncat", meloncat ke sana kemari tergantung arah mata angin kekuasaan. Kebenaran mutlak tadi, dalam dimensi sosial perlu ditransfer menjadi "kebenaran mutlak (hanya) untuk pemeluknya, bukan untuk mereka yang berada di luarnya. (Lihat PKUB Kemenag RI, 2015; Waskitoadi, 2017).

Kalau sepaham bahwa agama adalah sakral bagi pemeluknya, maka ketika kita hidup dalam masyarakat apalagi masyarakat plural seperti Indonesia ini, pemeluk masing-masing agama atau aliran keagamaan yang berbeda-beda tadi juga harus meyakini bahwa keragaman agama dan budaya masyarakat itu adalah mutlak adanya. Di sinilah dimensi sosiologis dari agama harus diejawantahkan dalam pikiran, sikap, dan tindakan yang memartabatkan kepada sesama. inilah "pesan agama: memperadabkan kehidupan". Untuk melangkah ke sana, dibutuhkan cara pandang bahwa "beda itu indah" atau setidaknya, "di dalam perbedaan, di sana selalu ada 
keindahan". Pertanyaannya, "sudahkah kita yang mengaku beragama memperindah kehidupan berdasarkan ajaran agama kita".

\section{c. Beda itu Indah}

Beda itu ancaman atau beda itu keindahan? Jika kita melihat perbedaan sebagai ancaman, apalagi perbedaan dalam hal agama, maka kita akan menyibukkan diri untuk menelusuri tingkah laku mereka yang berbeda agama yang menyimpang, baik dipandang dari sudut sosial, politik, hukum, dan bahkan faham keagamaannya.

Jika proposisi yang kita pilih bahwa beda itu ancaman, maka posisi yang kita pilih biasanya adalah sebagai intel sekaligus wasit yang dibekali dan membekali diri dengan segepok undang-undang agama yang kita pahami.

Meng-indah-kan kehidupan, tidak lalu berarti menghindar atau bahkan menafikan persaingan. Persaingan justru hadir sebagai anak kandung dari adanya keragamaan dan perbedaan. Kalau Karl Marx memposisikan manusia dalam suasana konflik karena memperebutkan peluang terbatas, dan Thomas Hobbes mengukuhkan dalam adagium: "manusia bagaikan serigala bagi manusia lainnya", tetapi agama mengajarkan pandangan yang berbeda. Agama menganjurkan bersaing dalam kerangka mencapai kemaslahatan umat manusia. Dalam persaingan, mendorong kita untuk meningkatkan kualitas kehidupan.

Dari sudut inilah terasa lebih penting untuk mempertanyakan "sumbangan agama dalam membangun peradaban masyarakat daripada disibukkan oleh saling mengklaim kebenaran dan menyalahkan pihak di luarnya. Biarkan masing-masing pihak mengekspresikan spirit keagamaan dalam kedamaian dan mendamaikan.

\section{d. Mendialogkan Peran Umat Beragama}

Agama bagi pemeluknya menghadirkan dua relasi secara seimbang, yakni relasi makhluk kepada Kholik-nya (relasi vertikal) dan relasi antarmakhluk (relasi horizontal) itu sendiri. Masing-masing dari internal pemeluk agama itu sendiri memiliki kadar pemahaman, sikap, dan perilaku keagamaan yang tidak sama, apalagi antarpemeluk dari agama yang berbeda. Dari sudut inilah kita yang diperlakukan oleh lingkungan sosial sebagai "tokoh agama" atau "tokoh masyarakat", perlu menggali peluang-peluang yang 
memungkinkan baik pada internal pemeluk agama yang sama maupun antarpemeluk agama yang berbeda, dalam kaitanya dengan kebutuhan pemenuhan relasi vertikal dan horizontal secara arif (bijak) (Lihat Mun'in DZ, 2003).

Dengan kata lain, bagaimana memulai mendialogkan dua hal penting yaitu posisi kita sebagai pemeluk suatu agama, dan posisi sebagai warga bangsa yang hidup dalam keragaman paham keagamaan termasuk perbedaan agama yang dipeluk sesuai dengan kadar kapasitas lingkungan sosial masing-masing.

Untuk menuju kepada "tradisi mendialogkan” kehidupan untuk sasaran akhir terwujudnya kerukunan, baik inter maupun antarpemeluk agama, bisa dalam tiga jenis dialog, yaitu (1) dialog keseharian; (2) dialog pemeranan; dan (2) dialog keimanan (lihat Effendi, 1995)

Dialog keseharian bisa dilakukan secara personal maupun secara komunal, bisa dalam interaksi spontan, nonformal maupun direncanakan dan bercorak komunal. Asumsinya bertolak pada konsep "tak kenal maka tak sayang". Dari "kenal" inilah kita mulai bisa berbagi pemahaman diri dan pihak lain, sekaligus mengurangi rasa curiga dan membenci.

Dialog pemeranan menggambarkan diri kita sebagai pemeluk agama punya kewajiban dan berikhtiar untuk memperbaiki kehidupan bersama. Bergotongroyong untuk menanggulangi bencana misalnya, merupakan satu moment penting bagaimana kita memerankan diri sebagai pemeluk agama sekaligus warga yang baik tanpa membeda-bedakan "anda agamanya apa?", tetapi justru memunculkan khusnudzon (prasangka positif), yakni "saya yakin dia orang beragama pasti baik perilakunya". Dalam paham Islam, spirit fastabiqul khoirat hadir. Berlomba dalam kebajikan. Dalam filosofi Jawa dikenal dengan ungkapan:

"Paringa obor marang wong kang kepetengan;

Paringa teken marang wong kang kelunyon; Paringa payung marang wong kang kudanan; Paringa unjukan marang wong kang keluwen; Paringa asih lan kinasih marang sepodo makhluke Gusti Kang Maha Asih (Thohir, 2018)

Jika dialog pertama dan kedua tadi sudah berjalan baik, maka dialog keimanan bisa dimulai. Dialog keimanan atau antar-iman di sini, bukan untuk mengoreksi ajaran keimanan masing-masing pemeluk agama yang berbeda-beda, tetapi belajar memahami 
di balik perbedaan-perbedaan agama dan ajarannya. Prinsip epistemologisnya ialah "menghormati hadir setelah kita mengerti".

\section{SIMPULAN}

Pertama, apa yang seharusnya dilakukan dan dibenahi; dengan cara bagaimana melakukan dan membenahi? Ada baiknya mendialogkan, sehingga kita tidak menjadi bagian dari manusia yang diamsalkan sebagai orang-orang buta yang bertengkar dalam mendifinisikan gajah.

Kedua, dialog antarumat hanya berjalan dengan baik kalau melalui tahapan-tahapan, seperti dialog kehidupan, dialog kerja bareng untuk merencanakan kerja gotongroyong atau bantuan kepada masyarakat yang terkena musibah, dan dialog teologis antarumat. Dialog teologis di sini, ditujukan untuk lebih memahami, mengerti, dan menghormati ajaran agama lain, bukan untuk menemukan kebenaran tunggal.

Ketiga, untuk terwujudnya dialog-dialog dan kerjasama itu, secara riil dibutuhkan adanya paguyuban-paguyuban lintas agama, terutama pada daerah kecamatan bahkan desa yang di dalamnya terdapat warga berbeda-beda agama yang dianutnya.

\section{DAFTAR PUSTAKA}

Abegebriel, A Maftuh (dkk). 2004. Negara Tuhan - The Themati Encyclopedia. Jakarta: SR-Ins Publishing.

A'la, Abd. 2006. "Cita-cita Sosial dalam Perspektif Islam: Menguak Mabadi Khoiru Ummah NU", dalam Jurnal Analisa, Vol. XVI, No. 19, Th. 2006. Hlm. 71 82.

Effendi, Bachtiar. 1997. "Masyarakat Agama dan Tantangan Global: Mempertimbangkan Konsep Deprivitasi Agama", dalam jurnal Ulumul Qur'an. No. 3, VII, hlm. $43-51$.

Mas’udi, Masdar F. 2009. “Islam (di) Indonesia. Kompas, Jumat, 11 September 2009, hlm. 6.

Mun'in DZ, Abdul. 2003. "Mempertahankan Keragaman Budaya" dalam Jurnal Tashwirul Afkar, Vol. XVI, No. 14, Th. 2003. Hlm. 2 -8. 
Nugroho, Singih dan Handoyo, Setyo (eds). 2016. Peta Potensi Konflik dan Kondisi Kebebasan Beragama/Berkeyakinan di Jawa Tengah. Salatiga: Pustaka Percik

PKUB Kemenag RI. 2015. Himpunan Peraturan tentang Layanan Negara terhadap Kehidupan Beragama. Jakarta: kemenag RI.

Thohir, Mudjahirin. 2013. Multikulturalisme - Agama, Budaya, dan Sastra. Semarang: Pustaka Mandiri.

. 2015. Kedewasaan Beragama dalam Masyarakat Plural. Semarang: Pustaka zaman.

. 2018. "Kearifan Lokal sebagai Modal Sosial Masyarakat untuk Mendesain Kerukunan Hidup Bersama dalam Perbedaan", dalam Tradisi Menghargai Diri Sendiri. (Fajrul Falah dan Agus Maladi Irianto, eds). Semarang: Fasindo Press.

Waskitoadi, Aguyng dkk. Eds. 2017. Proses Menjadi Indonesia: Negara, Kebebasan Beragama, dan Pernikahan Beda Agama. Salatiga: Percik. 